\title{
Do Braille Cells Influence Legibility of Texts for the Sighted?
}

\author{
Klementina MOŽINA, Igor MAJNARIĆ, Dorotea KOVAČEVIĆ
}

\begin{abstract}
Labels as a graphic product are important for information in declarations, especially for languages of smaller nations. Labels are increasingly required together with their ever more complicated technical performance, one of them being the desire to adapt the text to blind or partially sighted users. We therefore tested the possibility of using a declaration text in black with overprinted Braille cells with no or minor influence on legibility. The research was performed by analyzing the influence of printed cells on the achromatic halftone reproduction. The prints of the text and the overprinted Braille cells were made with a UV LED inkjet printer. Two different typefaces in two different sizes suitable for labelling were tested. The color properties were determined colorimetrically and the differences in the typographic tonal density of typefaces were measured with an image analysis. The legibility research was performed with the help of observers who read the plain printed text and the printed text in combination with overprinted Braille cells made with varnish. The results showed that an appropriate typeface and type size can reduce the influence of overprinted Braille on text legibility.
\end{abstract}

Keywords: DE2000 color difference; label declaration; legibility; typography; UV LED inkjet; varnish Braille cells

\section{INTRODUCTION}

In packaging design, self-adhesive labels have an important role for declarations, especially for languages of smaller nations. To protect and conserve goods, they used to be in most cases wrapped into cardboard or stored into cans. In the past decades, the impact of packaging design and appropriate labelling has increased, influencing and directing people's purchasing decisions $[1,2]$. On the other hand, packages need to contain information which communicates [3] how to appropriately store and use the product, and how to transport or recycle the package. Many packages, especially in the pharmaceutical industry, also require the text in Braille format to inform blind or partially sighted users [4-7]. Frequently, Braille characters appear over the text for sighted users. The most commonly used technique is paper or cardboard embossing [8]. Due to the thickness and dimension of the surface of labels being small, Braille letters cannot be made using a standard embossing technique, but the TRUCT (transparentresinous-ultraviolet-curing-type) method [9], a multilayer screen or UV inkjet printing technology.

ISO standard 17351 [10] defines the Braille text height for pharmaceutical packaging (for medicines). A standard procedure of measuring Braille dots is performed with a micrometer calibrated with a spring (loaded force of not less than $0,5 \mathrm{~N}$ on three points of printed text). For medical products made in inkjet and screen printing technology, the cell dot height should be $0,20 \mathrm{~mm}$ with no more than $5 \%$ of Braille cell dots measuring less than $0,12 \mathrm{~mm}$. A more accurate measurement method is based on measuring the Perthometer profile [11].

A substantial amount of research on legibility shows its importance [12-14] for a good presentation of visual information to people with normal or corrected-to-normal vision. Attention needs to be paid to a number of typographic characteristic to make a text more legible, i.e. counter shape, $\mathrm{x}$-height, ascender, descender, serifs, stroke weight, set width, type size, leading etc. [15-17]. In the visualization of information, typographic tonal density (or typographic tonality) has a significant influence. The typographic tonal density of different typographic elements refers to the relative blackness or shades of grey of type on a printed area. It can be expressed as the relative amount of ink per square centimeter, pica or inch [18]. The changes in various type features can create variations in typographic tonal density $[15,19]$. In a small type size, the differences in typographic tonal density that are influenced by the difference in stroke width are important $[14,20]$, since they have a great impact on text legibility. A thinner stroke width contains less ink per area and vice versa $[14$, 19, 21]. Therefore, typefaces printed in smaller type sizes should have moderate $\mathrm{x}$-height to ensure proper legibility $[16,17,22,23]$. In this research, we were interested in the type sizes that are mostly used in declarations on labels, e.g. 6 and 8 pt.

One of the non-impact printing (NIP) technologies the use of which is leading in many different areas of application is the inkjet technology [24, 25]. Additionally, it has become very useful in protecting printed products or improving their effects, e.g. with an extra varnish or even with more layers of varnish [26-28]. The UV printing and varnishing inkjet technology require more liquid ink and varnish (viscosity smaller than 0,5 Pas). Inks and varnishes thus have a higher content of diluents and a reduced content of epoxy resins. A typical UV cured black ink contains carbon pigments $(1-5 \%)$, acrylate amine synergist $(10$ $20 \%$ ), hexamethylene diacrylate hexane 1,6 diol diacrylate (25 - 35\%), acrylic esters $(30-40 \%)$, photosensitive monomers $(10-20 \%)$ and phosphine oxide derivative (5 $15 \%)[29,30]$. The type and structure of the printing substrate plays an important role in the realization of a UV cured varnish. Rough and absorptive substrates only change the color tone, but not the gloss. The possibility of obtaining matt or gloss surfaces also depends on the settings of varnishing (i.e. possibility of defining varnish area in halftones) and on the activation number of UV lamps, e.g. two UV LED lamps with different activation periods can achieve either a matt or gloss surface [31-33].

The aim of the research was to find out whether the varnish layers for Braille cells influence with their gloss properties the legibility of the text for the sighted.

\section{METHODS}

\subsection{Substrate Properties}

The prints for the research were made on a white matt vinyl self-adhesive film (label foil). Before the printing, the 
samples of label foil (substrate) were conditioned according to the ISO 187 standard [34], and their basic surface and optical properties were measured. Substrate thickness was measured according to the ISO 534 standard [35]. Specular gloss was measured in accordance with the ISO 2813 standard [36]. Brightness was measured according to the ISO 2470-1 standard [37]. Opacity was measured in line with the ISO 2471 standard [38]. The measured properties of the label foil are given in Tab. 1 .

Table 1 Properties of printing substrate vinyl self-adhesive film

\begin{tabular}{|c|c|}
\hline Properties & Values \\
\hline Thickness / mm & 0,80 \\
\hline Gloss / \% & 8 \\
\hline Brightness / \% & 94 \\
\hline Opacity / \% & 100 \\
\hline
\end{tabular}

\subsection{Colorimetric, Typographic and Braille Cell Properties of Prints}

Black and varnish prints were made with a piezo inkjet technology using an LED UV Inkjet LEC-300 (Roland, Japan). The used ECO UV EUV4 GL varnish was composed of acrylated amine synergist (10 - 50\%), hexamethylene diacrylate hexane 1,6-diol diacrylate (25$35 \%)$, acrylic esters $(30-40 \%)$, other photo sensitive monomers (10 - 40\%) and phosphine oxide derivative (5 $15 \%$ ). The composition of the used black ink (ECO UV EUV4 BK) was identical to the UV black ink; however, it contained additional colorants ( $1-5 \%$ carbon pigments) [30]. In the original ink cartridge, the liquid viscosity was 6 - 8 mPas.

For varnish prints, we used 14 layers. The achieved height of varnish Braille cells was $0,172 \mathrm{~mm}$. The model for measuring the profile of a typical Braille cell created with several layers was a Perthometer S8P (Pethen, Germany) (cf. Fig. 1).

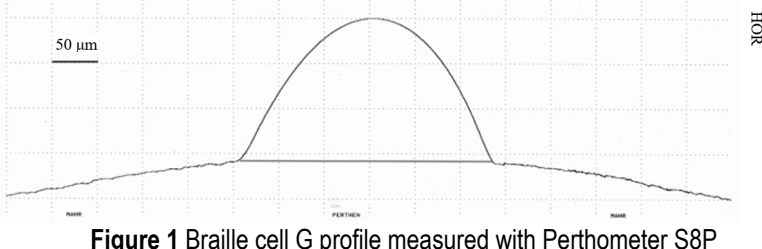

Two different typefaces with differences in stroke width were tested, i.e. one old-style (Palatino) $[21,39,40]$ and one transitional typeface (Times) $[21,39,40]$, in two different sizes, i.e. 6 and 8 pt. The two serif typefaces were selected for our research as serifs improve legibility at small type sizes [41].

During the reproduction of achromatic halftone images, it is necessary to perform screening. In inkjet printing, this process was conducted using software Raster Image Processor (RIP) Wersawork. The test printing form consisted of two separations, i.e. black ink from 10 to $100 \%$ tone value (TV) (with step of $10 \%$ TV) and varnish separation with multiplicate Braille cells. The test form was created with the Adobe InDesign software and saved as a PDF file.

The CIE $L^{*} a^{*} b^{*}$ parameters of white prints were measured with a spectrophotometer eXact (X-rite, USA) in accordance with the ISO 13655 standard [42]. The color difference was calculated according to the CIE LAB DE2000 definition [43].

The typographic tonal density of typefaces was measured with the software (ImageJ) for image analysis [44].

\subsection{Legibility}

Various texts were printed in different typefaces in different sizes with and without overprinted Braille characters. Texts of popular science were used to avoid the influence of specific or unknown subjects to observers. The length of texts was between 559 and 1009 characters. The time needed to read 600 characters (in seconds) was calculated based on the time required for reading the whole text. To check the observers' recognition of the text, the proportion of correct responses to multiple-choice questions (with two-response alternatives) was examined.

The observers $(N=20)$ were aged between 19 and 23 years $(M=21,30$ years, $S D=3,8)$ with normal or correctedto-normal vision. They read the texts at the same conditions of lighting and viewing distance. Each participant read all 8 texts $(2$ typefaces $\times 2$ sizes $\times 2$ samples; i.e. with or without Braille cells), which were presented in random order to different participants to eliminate possible order effects.

The influence of the typeface, type size and effect of overprinted Braille characters made with varnish on legibility was statistically analyzed with the IBM SPSS 23 software. A three-way repeated measures analysis of variance with the time needed to read 600 characters as a dependent variable was performed. McNemar's tests were performed to investigate the influence of samples on observers' correct responses. Statistical hypotheses were tested at 0,001 alpha error rate.

In the research, we wanted to establish how overprinted Braille cells with UV LED cured gloss varnish influence the legibility of printed information. Additionally, we were interested in the possibility of using a declaration text in black with overprinted Braille. We therefore compared the text legibility of overprinted Braille cells made with varnish with the legibility of plain prints in black.

\section{RESULTS AND DISCUSSION \\ 3.1 Colorimetric Properties of Substrate and Prints}

Fig. 2 depicts the CIE $L^{*} a^{*} b^{*}$ values of prints with $100 \%, 90 \%, 80 \%, 70 \%, 60 \%, 50 \%, 40 \%, 30 \%, 20 \%$ and $10 \%$ tonal value (TV), while Fig. 3 shows the difference in CIE LAB DE2000 between the prints with Braille and without Braille.

The obtained results show (cf. Fig. 2 and Fig. 3) that the substrate printed only with varnish (without the application of black UV LED inkjet ink) achieved a higher visual color change $(D E=4,5)$ (cf. Fig. 3). The reason for this deviation lies in $b^{*}$ coordinates (cf. Fig. 2), which was a result of a not perfectly dried, transparent UV LED varnish. The solid printed black tone was also homogeneous, whereas the low lightness value $\left(L^{*}\right)$ of black ink compensated for the yellowness of the UV LED curable varnish. The latter resulted in a smaller color change $(D E=2,28)$, which was visible with the naked eye. 


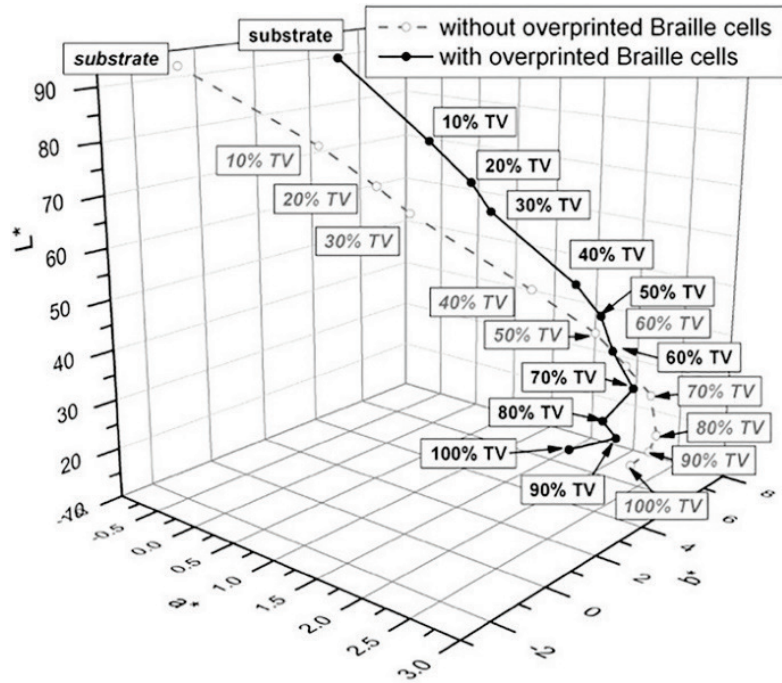

Figure $2 \mathrm{CIE} L^{*} a^{*} b^{*}$ values of substrate (0\% TV) and prints with $100 \%, 90 \%$ $80 \%, 70 \%, 60 \%, 50 \%, 40 \%, 30 \%, 20 \%$ and $10 \%$ tonal value (TV) with and without overprinted Braille cells

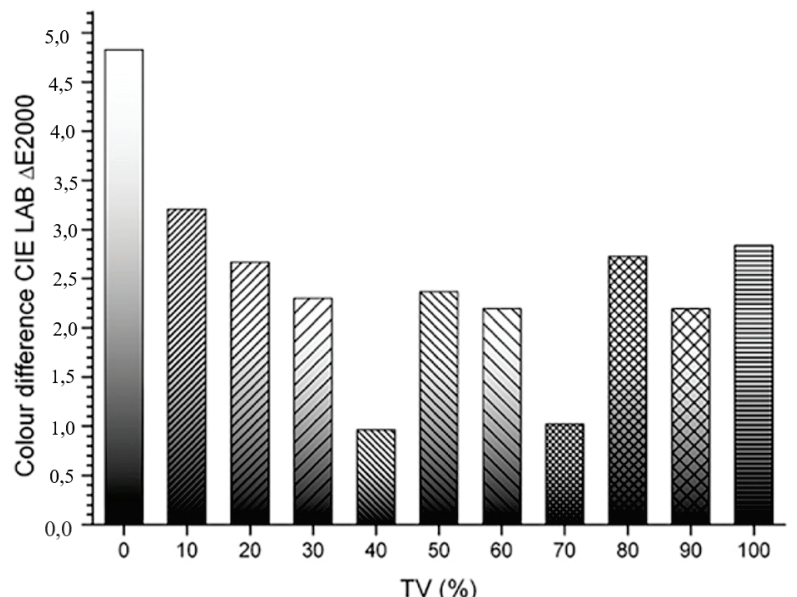

Figure 3 CIE LAB DE2000 differences of substrate and prints with and without overprinted Braille cells

By increasing the surface coverage (TV), the color difference between black prints and print samples overprinted with Braille cells reduced (cf. Fig. 3). The lowest DE value was achieved in the surface coverage with $40 \% \mathrm{TV}$. The tonal value of $70 \%$ print coverage was similar to that of a patch with $40 \% \mathrm{TV}$. In this printing area, the relations between the printed and non-printed elements were similar.

Nevertheless, in our case, the rule was inversely proportional. In the middle tone areas, the optical dot gain had the highest value. This fact also contributed to a higher tone difference. Darker, achromatic tones printed with UV inkjet printing were reproduced similarly. The tone deviations when printing Braille cells were mainly seen on chroma coordinates. By printing a standard black text, the integral density depended on the typeface and type size.

\subsection{Typographic Properties of Prints}

The typographic tonal density (TTD) of each typeface, each in different size, overprinted or not overprinted with Braille cells was measured. The samples of studied typefaces, $6 \mathrm{pt}$ in size, overprinted with Braille characters are presented in Fig. 4. The prints with the typographic tonal density for each typeface in different size, overprinted or not overprinted with Braille are presented in Fig. 5.

The results showed higher typographic tonal density at the transitional typeface Times (cf. Fig. 5). The old-style Palatino (cf. Fig. 4 and Fig. 5) does not show great differences between thick and thin strokes, while its counter size is relatively big. On the other hand, the transitional Times has evident differences between thick and thin strokes, and smaller counter size. Moreover, smaller type sizes give higher typographic tonal density than bigger type sizes. This was according to a smaller counter size of letters and leading also expected.

\section{opru. To je izredno zanimi logo odprtih yprašanj ter mo- $\checkmark$ izzivov. Z digitalizacijo st zato je tako fascinantna. $\mathrm{Ne}$ avo, ki bo za večno ohrani. I novega, cesar še niȟ̌e prej sali smo tim bolj ohraniti $i$ : tarega epigrafskega napisa na i nihovo strukturo in se jir , saj nam jẹ odprla mnogo no Figure 4 Sample of typefaces Palatino (left) and Times (right) in size 6 pt overprinted with Braille cells}

According to the results (cf. Fig. 5), the influence of overprinted varnish Braille cells on typographic tonal density can be noticed. On average, a more substantial influence could be seen at the transitional Times, which is due to its smaller counter size. Furthermore, the influence of overprinted varnish was more evident at smaller type sizes. Nevertheless, the major difference in typographic tonal density appeared among type sizes, and not among the prints with overprinted and not overprinted varnish.

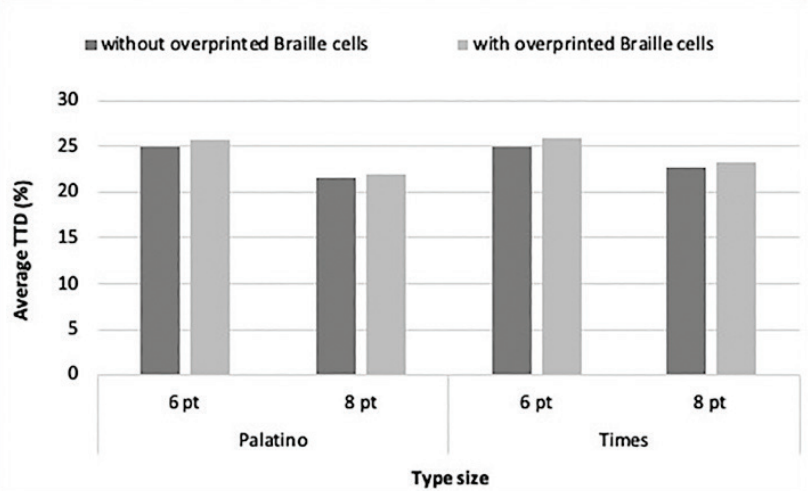

Figure 5 Typographic tonal density (TTD) of tested typeface Palatino and Times in sizes 6 and 8 pt with and without overprinted Braille cells

\subsection{Legibility of Prints}

Fig. 6 - Fig. 9 show the influence of the used typefaces, type sizes, and varnish for the overprint on the speed of reading and number of correct responses.

According to the results (cf. Fig. 6), the statistical analysis revealed that there was a significant effect of the typeface on the reading speed, $F(1,19)=19,44, p<0,001$. It indicated that participants spent more time reading the text in the Times typeface $(M=28,81 \mathrm{~s}, S D=5,87)$ than the text in the Palatino typeface $(M=26,88 \mathrm{~s}, S D=5,66)$. Additionally, the reading time was influenced by the typeface size (cf. Fig. 6), $F(1,19)=57,29, p<0.001$. It was longer for the text in $6 \mathrm{pt}(M=29,39 \mathrm{~s}, S D=5,34)$ than the text in 8 pt $(M=26,30 \mathrm{~s}, S D=5,91)$. At both sizes, the reading speed was faster at the old-style Palatino typeface. The Palatino letters have no very noticeable variations in stroke thickness, their counter size is bigger than Times' letter counter size, and their serifs are moderate. There was 
a statistically significant effect of the overprinted Braille characters (cf. Fig. 7 and Fig. 8), $F(1,19)=380,79, p<$ 0,001 , suggesting that the texts with overprinted Braille characters were read more slowly $(M=32,71 \mathrm{~s}, S D=3,45)$ than the texts without them $(M=22,99 \mathrm{~s}, S D=2,94)$. The analysis did not indicate any significant interaction effect among all the other factors, which means that the overprinted Braille cells slowed the reading speed, regardless of the typeface or type size.

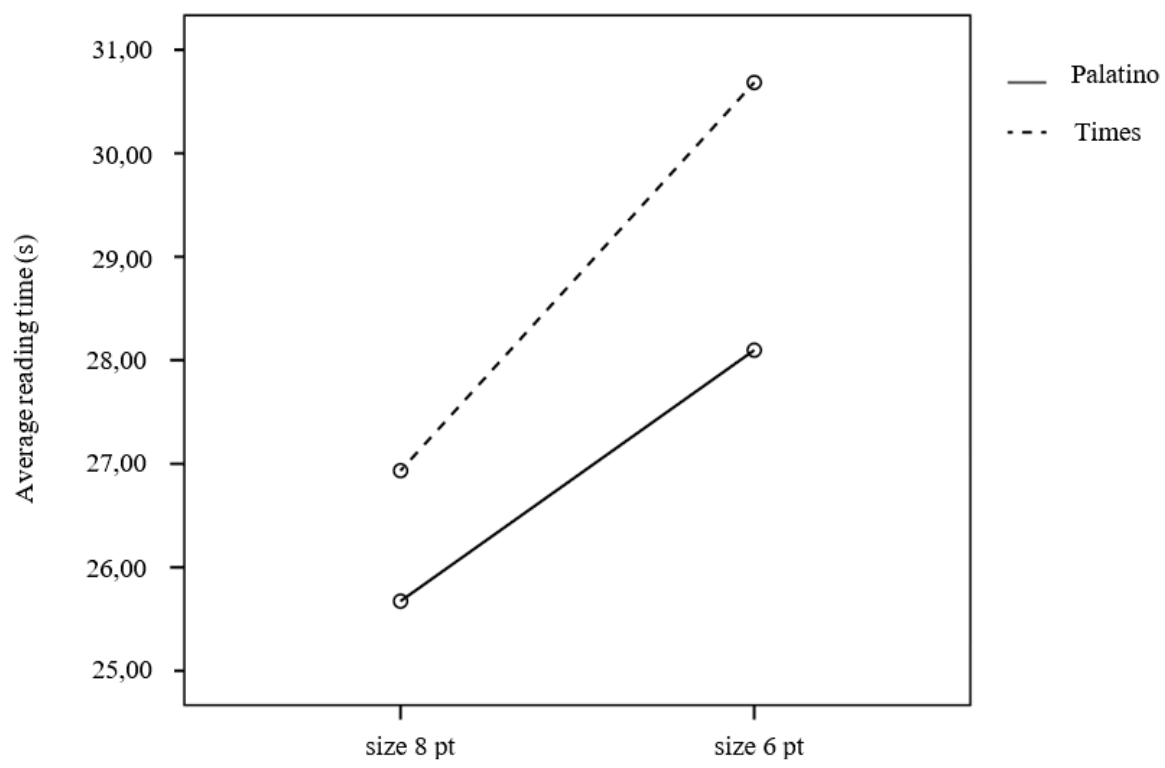

Figure 6 Average reading time for different typefaces and sizes

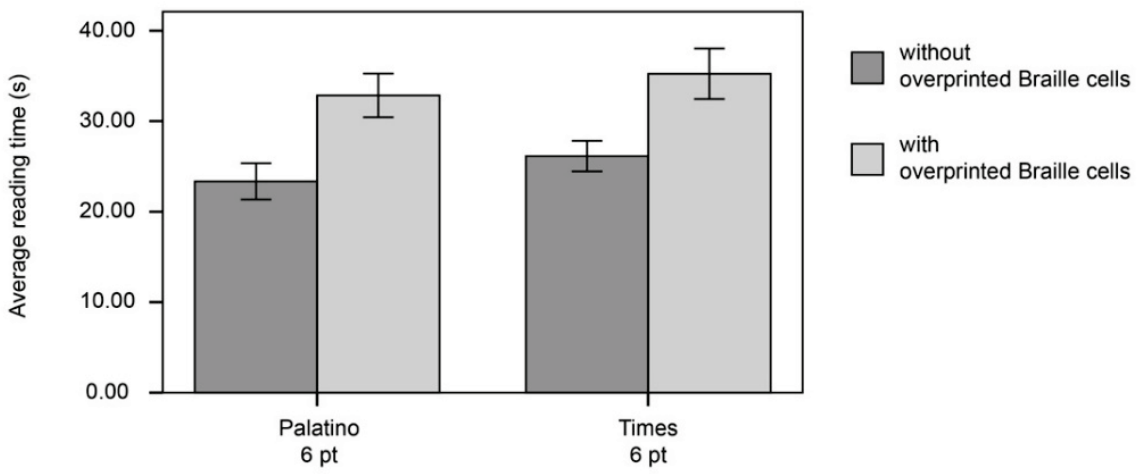

Figure 7 Average reading time for texts in 6 pt with and without overprinted Braille cells

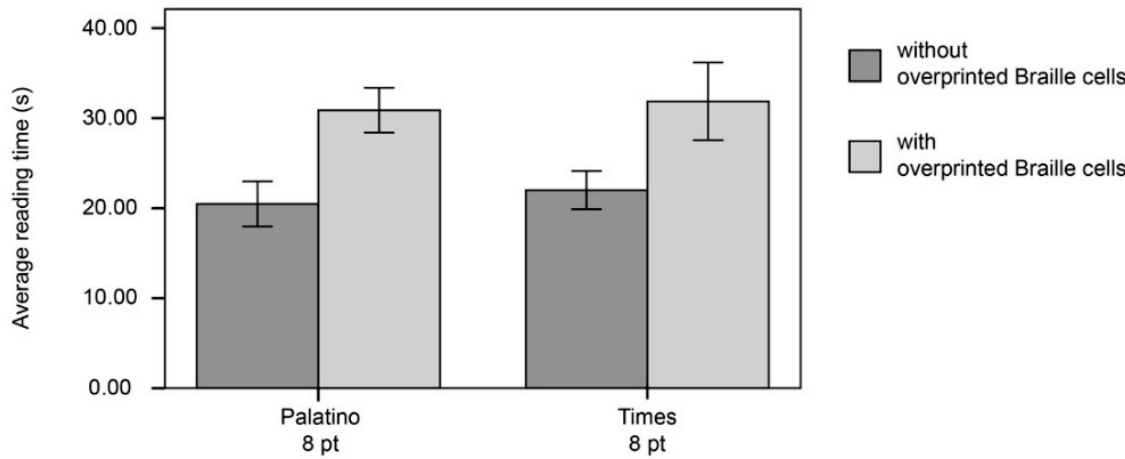

Figure 8 Average reading time for texts in 8 pt with and without overprinted Braille cells

McNemar's tests were performed to investigate the influence of the typeface, size and use of overprinted Braille characters on the participants' correct responses (cf. Fig. 9). Although the number of correct answers was higher for the text in the Palatino typeface $(88,8 \%)$ than for the text in Times $(86,3 \%)$, the difference between these two typefaces was not statistically significant, $p=0,82$. Similarly, there was no significant difference among different typeface sizes, although participants provided more correct responses for the text in $8 \mathrm{pt}(90 \%)$ than for 
the text in $6 \mathrm{pt}(85 \%), p=0,42$. In addition, despite participants giving more correct answers when reading the text without overprinted Braille characters $(91,3 \%)$ in comparison to when it was overprinted $(83,8 \%)$, this difference was not found to be statistically significant, $p=$ 0,24 .
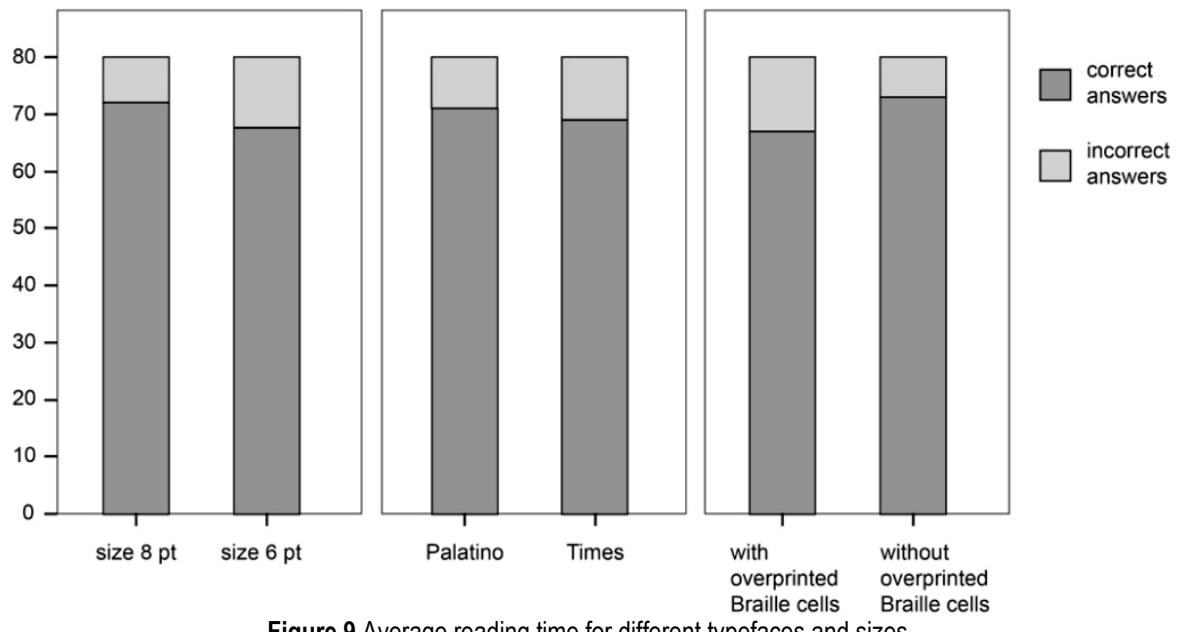

Figure 9 Average reading time for different typefaces and sizes

\section{CONCLUSIONS}

As labels are important for information on declarations, especially for languages of smaller nations, the printing quality and legibility of labels need to be taken into consideration. The aim of the research was to establish how overprinted Braille cells made with varnish influence legibility of printed information and if there is a possibility to use a declaration text with overprinted Braille. We compared the legibility of a text overprinted with Braille cells made with varnish with the legibility of prints with plain texts in black.

The obtained results revealed that the most visible effect of Braille cells was observed on an unprinted substrate. Black prints overprinted with Braille achieved the smallest color difference in the tonal value of $40 \%$. Also, black prints overprinted with Braille cells increased the value of typographic tonal density, which impeded the reading speed, especially at the smallest type size $(6 \mathrm{pt})$. However, it seems that the legibility of a black text overprinted with Braille cells can be improved by choosing an appropriate typeface. The old-style typeface Palatino gave the best legibility results among the tested typefaces. The advantage is in its typeface design. This typeface has a moderate counter shape, which enables faster reading and consequently better legibility. The latter is especially noticeable at smaller type sizes.

However, for the results to be even more relevant, more thorough research should be conducted also with elderly observers.

Our results suggest that an appropriate typeface and type size can have a positive influence on the legibility of a text, even when overprinted with Braille characters. We therefore conclude that label declaration can be overprinted with Braille letters, giving information at the same time to people with normal or corrected-to-normal vision, and to the blind or partially sighted people.

\section{REFERENCES}

[1] Bix, L., Rifon, N., Lockhart, H., \& de la Fuente, J. (2008). The Packaging Matrix: Linking Package Design Criteria to the Marketing Mix. IDS Packaging. Retrieved from http://www.idspackaging.com/Common/Paper/Paper_47/Pd flmge.pdf

[2] Clement, J. (2007). Visual influence on in-store buying decisions: an eye-track experiment on the visual influence of packaging design. Journal of Marketing Management, 23(910), 917-928. https://doi.org/10.1362/026725707X250395

[3] Gomes, T., Hurley, R. A., Duchowski, A., Darby, D., \& Ouzts, A. (2014). The Effect of Full Body Versus Partial Body Graphic Labelling on Beverage Packaging. Packaging Technology and Science, 27(12), 933-943. https://doi.org/10.1002/pts.2070

[4] European Blind Union. (2019, April). Retrieved from http://www.euroblind.org

[5] Krivec, T., Muck, T., Fugger Germadnik, R., Majnarić, I., \& Golob, G. (2014). Adapting Artworks for People Who Are Blind or Visually Impaired Using Raised Printing. Journal of Visual Impairment \& Blindness, 108(1), 68-76. https://doi.org/10.1177/0145482X1410800108

[6] Macik, M., (2018). Cognitive Aspects of Spatial Orientation. Acta Polytechnica Hungarica, 15(5), 149-167. https://doi.org/10.12700/APH.15.5.2018.5.9

[7] Baranyi, P. \& Csapo, A. (2012). Definition and Synergies of Cognitive Infocommunications. Acta Polytechnica Hungarica, 9(1), 67-83.

[8] Kibirkštis, E., Venytė, I., Mayil, V., \& Vakulich, D. (2011). Investigation of geometrical and physical - mechanical parameters of Braille by assessing the different types of cardboard materials. Mechanics, 17(6), 656-660. https://doi.org/10.5755/j01.mech.17.6.1010

[9] Doi, K., Fujimoto, H., \& Wada, T. (2009). Influence of Base Material of TRUCT Braille on Readability of TRUCT Braille. IFMBE Proceedings 25/IX, Munich, 235-238. https://doi.org/10.1007/978-3-642-03889-1_63

[10] ISO 17351. (2014). Packaging - Braille on packaging for medicinal products. Geneva: ISO.

[11] ISO 5436-1. (2000). Dimensional and geometrical product specifications and verification: Surface texture: Profile method; Measurement standards - Part 1: Material measures. Geneva: ISO.

[12] Bix, L., Lockhart, H., Selke, S., Cardoso, F., \& Olejnik, M. (2003). Is x-height a better indicator of legibility than type size for drug labels? Packaging Technology and Science, 16(5), 199-207. https://doi.org/10.1002/pts.625 
[13] Tai, Y., C., Sheedy, J., \& Hayes, J. (2006). Effect of letter spacing on legibility, eye movements, and reading speed. Journal of Vision, 6(6), 994-994. https://doi.org/10.1167/6.6.994

[14] Možina, K., Podlesek, A., \& Bračko, S. (2019). Preserving typographic cultural heritage using contemporary digital technology. Journal of Cultural Heritage, 36(2), 166-173. https://doi.org/10.1016/j.culher.2018.07.010

[15] Reynolds, L. (1988). Legibility of Type. Baseline, 10, 26-29.

[16] Gaultney, V. (2001). Balancing Typeface Legibility and Economy: Practical Techniques for the Type Designer [research essay]. Reading: University of Reading.

[17] Tracy, W. (2003). Letters of Credit: A View of Type Design. Boston: David R.

[18] Keyes, E. (1993). Typography, color, and information structure. Technical Communication, 40(4), 638-654.

[19] Možina, K., Možina, K., \& Bračko, S. (2013). Non-invasive methods for characterisation of printed cultural heritage. Journal of Cultural Heritage, 14(1), 8-15. https://doi.org/10.1016/j.culher.2012.02.012

[20] Rat, B., Možina, K., Bračko, S., \& Podlesek, A. (2011). Influence of Temperature and Humidity on Typographic and Colorimetric Properties of Ink Jet Prints. Journal of Imaging Science and Technology, 55(5), 050607-1-050607-8. https://doi.org/10.2352/J.ImagingSci.Technol.2011.55.5.050607

[21] Bringhurst, R. (2002). The Elements of Typographic Style. Point Roberts: Hartley \& Marks.

[22] Wilkins, A., Cleave, R., Grayson, N., \& Wilson, L. (2009). Typography for children may be inappropriately designed. Journal of Research in Reading, 32(4), 402-412. https://doi.org/10.1111/j.1467-9817.2009.01402.x

[23] Legge, G. E. \& Bigelow, C. A. (2011). Does print size matter for reading? A review of findings from vision science and typography. Journal of Vision, 11(5), 1-22. https://doi.org/10.1167/11.5.8

[24] Soleimani-Gorgani, A. (2016). Inkjet Printing. Printing on Polymers. Amsterdam: Elsevier, 231-247. https://doi.org/10.1016/B978-0-323-37468-2.00014-2

[25] Piezo Institute. (2019, February). Retrieved from http://www.piezoinstitute.com

[26] Kipphan, H. (2001). Handbook of print media: technologies and production methods. Heidelberg: Springer. https://doi.org/10.1007/978-3-540-29900-4

[27] Dolić, J., Pibernik, J., \& Majnarić, I. (2014). Influence of UV Varnish Pattern Effect on Print Quality. Journal of Imaging Science and Technology, 58(6), 060501-1-060501-9. https://doi.org/10.2352/J.ImagingSci.Technol.2014.58.6.060501

[28] Možina, K., Majnarić, I., \& Rat, B. (2016). Label legibility influenced by different number of white ink layers. Technical Gazette, 23(3), 775-781. https://doi.org/10.17559/TV-20150312204707

[29] Lee, E. R. (2003). Microdrop Generation. Boca Raton: CRC Press, 230-240.

[30] ECO - UV Inks. (2019, February). Retrieved from https://www.rolanddga.com/products/inks/eco-uv-inks.

[31] Edison, S. E. (2010). The Chemistry of Ink Jet Inks. Singapore: World Scientific Publishing 161-176. https://doi.org/10.1142/9789812818225_0009

[32] Majnarić, I., Bolanča-Mirković, I., \& Golubović, K. (2012). Influence of UV Curing Varnish Coating on Surface Properties of Paper. Technical Gazette, 19(1), 51-56.

[33] Jančovičová, V., Mikula, M., Havlínová, B., \& Jakubíková, Z. (2013). Influence of UV-curing conditions on polymerization kinetics and gloss of urethane acrylate coatings. Progress in Organic Coatings, 76(2-3), 432-438. https://doi.org/10.1016/j.porgcoat.2012.10.010

[34] ISO 187. (1990). Paper, board and pulps: Standard atmosphere for conditioning and testing and procedure for monitoring the atmosphere and conditioning of samples. Geneva: ISO.

[35] ISO 534. (1997). Paper and board: Determination of thickness and apparent bulk density or apparent sheet density. Geneva: ISO.

[36] ISO 2813. (2014). Paints and varnishes - Determination of gloss value at $20^{\circ}, 60^{\circ}$ and $85^{\circ}$. Geneva: ISO.

[37] ISO 2470-1. (2016). Paper, board and pulps: Measurement of diffuse blue reflectance factor - Part 1: Indoor daylight conditions (ISO brightness). Geneva: ISO.

[38] ISO 2471. (1998). Paper and board: Determination of opacity (paper backing) - Diffuse reflectance method. Geneva: ISO

[39] McLean, R. (1996). The Thames and Hudson Manual of Typography. London: Thames and Hudson.

[40] Hyndman, S. (2016). Why fonts matter. London: Virgin Books.

[41] Lund, O. (1997). Why serif are (still) important. Typography papers, 3, 91-104.

[42] ISO 13655. (2017). Graphic technology: Spectral measurement and colorimetric computation for graphic arts images. Geneva: ISO.

[43] Luo, M. R., Cui, G., \& Rigg, B. (2001). The Development of the CIE 2000 Colour - Difference Formula: CIEDE2000. Color Research and Application, 26(5), 340-350. https://doi.org/10.1002/col.1049

[44] National Institutes of Health. (2019, March). Retrieved from http://rsb.info.nih.gov/ij/

\section{Contact information}

Klementina MOŽINA, full prof. dr. sc

(Corresponding author)

University of Ljubljana, Faculty of Natural Sciences and Engineering,

Snežniška 5, 1000 Ljubljana, Slovenia

E-mail: klementina.mozina@ntf.uni-lj.si

Igor MAJNARIĆ, assoc. prof. dr. sc

University of Zagreb, Faculty of Graphic Arts,

Getaldićeva 2, 10000 Zagreb, Croatia

E-mail: imajnari@grf.hr

Dorotea KOVAČEVIĆ, dr. sc.

University of Zagreb, Faculty of Graphic Arts

Getaldićeva 2, 10000 Zagreb, Croatia

E-mail: dorotea.kovacevic@grf.h 